\title{
Evaluation of Risk Factors for Exchange Range Hyperbilirubinemia in Neonates from Eastern Part of Nepal
}

\section{Sunil Kumar Yadav, Arun Giri and Babita Khanal}

Department of Paediatrics and Neonatology, Nobel Medical College Teaching Hospital, Biratnagar, Nepal

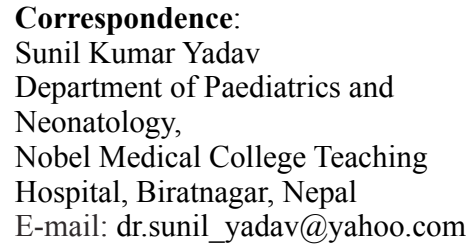

DOI: $10.3126 /$ jnps.v41i1.31040

Submitted on: 2020-09-06

Accepted on: 2021-02-20

Acknowledgements: None

Funding: Nil

Conflict of Interest: None declared

Permission from IRB: Yes
To cite this article: Yadav SK, Giri A, Khanal B. Evaluation of Risk Factors for Exchange Range Hyperbilirubinemia in Neonates from Eastern Part of Nepal. J Nepal Paediatr Soc. 2021;41(1):67-72.

\begin{abstract}
Introduction: Neonatal hyperbilirubinemia continues to be the commonest cause of nursery and NICU admissions and readmissions in the neonatal period worldwide. Although most cases are physiological, toxic levels of un-conjugated bilirubin can lead to acute and chronic bilirubin encephalopathy. Hence, this study aimed to study the risk factors for exchange range hyperbilirubinemia in neonates.
\end{abstract}

Methods: This was a hospital-based prospective observational study conducted in a teaching and referral NICU over a period of one year from July 2019 to August 2020. All neonates with diagnosis of hyperbilirubinemia requiring double volume exchange transfusion were included in the study. Risk factors for significant hyperbilirubinemia were analysed with descriptive statistics. P-value of $<0.05$ was considered significant wherever applicable.

Results: The mean gestational age and birth weight were $38.06 \pm$ 2.13 wks and $2611.72 \pm 389.39$ gm respectively. Fifteen percent of the babies (162) developed hyperbilirubinemia and 28 (17.3\%) required double volume exchange transfusion. Among neonates requiring exchange transfusion, 17 were females and 11 were males. Among 28 babies who required DVET, 20 (71.4\%) were SGA. ABO incompatibility was present in $14(50.0 \%)$ neonates and $\mathrm{Rh}$ incompatibility in $13(46.4 \%)$ neonates. $\mathrm{ABO}$ along with $\mathrm{Rh}$ incompatibility was present in eight $(28.6 \%)$ neonates. DCT was positive in six neonates with $\mathrm{ABO}$ incompatibility and nine neonates in Rh incompatibility. G6PD deficiency was present in four $(14.3 \%)$ neonates.

Conclusions: The most important risk factors identified were small for gestational age, $\mathrm{ABO}$ and $\mathrm{Rh}$ incompatibility followed by oxytocin use and sibling treated for jaundice.

Key words: Hyperbilirubinemia; Neonate; Risk factors

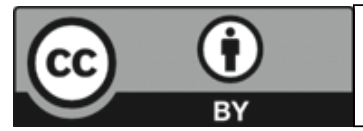

This work is licensed under creative common attribution 3.0 license 


\section{INTRODUCTION}

Neonatal jaundice affects up to $84 \%$ of term newborns and is the most common cause of hospital readmission in the neonatal period. ${ }^{1,2}$ Severe hyperbilirubinemia \{total serum bilirubin (TSB) level of more than $20 \mathrm{mg} / \mathrm{dL}\}$ occurs in less than $2 \%$ of term infants and can lead to kernicterus (i.e., chronic bilirubin encephalopathy) and permanent neurodevelopmental delay. ${ }^{2}$ Therefore, it is important to systematically evaluate all infants for hyperbilirubinemia. Acute bilirubin encephalopathy develops in one in 10,000 infants and presents with hypertonia, arching, retrocollis, opisthotonos, fever, and high-pitched cry. ${ }^{2}$ Data on progression of acute bilirubin encephalopathy to kernicterus are limited, but one study found that $95 \%$ of infants with acute bilirubin encephalopathy had full resolution of symptoms, and 5\% had evidence of kernicterus by the time of discharge. ${ }^{3}$ Kernicterus develops in one in 100,000 infants and manifests as athetoid cerebral palsy, auditory dysfunction, dental dysplasia, paralysis of upward gaze, and variable intellectual disability.

Risk factors for the development of severe hyperbilirubinemia include cephalhematoma or significant bruising, early gestational age, exclusive breastfeeding (especially unsuccessful breastfeeding and / or weight loss of $8 \%$ to $10 \%$ ), isoimmune or other hemolytic anemia, and a sibling with a history of neonatal jaundice. ${ }^{4}$ In addition to hyperbilirubinemia, earlier gestational age, hemolysis, sepsis, and low birth weight are associated with the development of bilirubin encephalopathy. One study found that less than 5\% of healthy term infants with a TSB level greater than $30 \mathrm{mg} / \mathrm{dL}$ developed acute bilirubin encephalopathy or kernicterus. ${ }^{3}$

Although there are various studies regarding neonatal hyperbilirubinemia in our country, there is paucity of data regarding the risk factors for exchange transfusion. Hence this study was conceptualised to identify the risk factors for exchange range hyperbilirubinemia in neonates of our geographical region.

\section{METHODS}

The study was conducted in a seventeen bedded NICU of Nobel Medical College Teaching Hospital (NMCTH), Biratnagar, Nepal which is a teaching hospital and tertiary care referral centre situated in the Eastern part of Nepal. The study was conducted over a period of one year from July 2019 to August 2020 in NICU of NMCTH. This was a hospitalbased prospective observational study. The study was commenced after approval from ethical review committee. All neonates presenting with neonatal hyperbilirubinemia with gestational age of $\geq 35$ weeks with hyperbilirubinemia in exchange range according to the American Academy of Paediatrics (AAP) 2004 were included in the study after taking the informed consent from the parents. ${ }^{5}$ Neonates with conjugated hyperbilirubinemia, persistence of hyperbilirubinemia beyond four weeks of life, and severe congenital malformations, and those who did not give consent were excluded from the study. After taking written informed consent in the local language from the parents and/or guardians, detailed history, examination, and investigations were performed and noted down. The total serum bilirubin (TSB) levels were measured using Pearlman and Lee Diazo method. Investigations conducted in all neonates requiring double volume exchange transfusion (DVET) were total serum bilirubin (TSB), conjugated and un-conjugated fractions of TSB, $\mathrm{ABO}$ and Rhesus blood group, direct coombs' test (DCT), reticulocyte count and peripheral blood smear. Glucose-6-phosphate dehydrogenase (G6PD) levels, thyroid profile, and septic screen were done wherever indicated. For each patient, data on birth weight, adequacy for gestational age, gender, age of onset of jaundice, age at presentation in NICU, TSB, occipito-frontal circumference and other relevant medical conditions were collected.

Descriptive statistics was performed for all the studied variables. Some of them were then categorised according to the frequency analysis and Chi-square test was used for categorical variables. The level of statistical significance adopted was $p<$ 0.05 wherever applicable. SPSS for Windows 20.0 software was used for all statistical analysis. 


\section{RESULTS}

During the study period, 1080 neonates were admitted into our NICU. Out of the total 1080 neonates admitted, $162(15.0 \%)$ had neonatal hyperbilirubinemia. Of these, $134(82.7 \%)$ required phototherapy and $28(17.3 \%)$ required double volume exchange transfusion (DVET) and hence 28 neonates fulfilled the inclusion criteria. Out of 28 neonates who required DVET, 17 were females and 11 were males. Among 162 neonates, 74 (45.7\%) neonates were small for gestational age (SGA). Out of 28 babies who required DVET, 20 (71.4\%) were SGA. The clinical parameters and demographics of the neonates who developed jaundice are presented in Table 1.

Most of the babies (71.4\%) were SGA in exchange range group. There was a history of sibling treated for jaundice in $15(53.6 \%)$ neonates, whereas oxytocin use during labor in 11 (39.3\%) mothers of neonates who required DVET. There was no history of delayed cord clamping in any neonates. History of birth asphyxia was present in 25 neonates. In those cases, Apgar score was 6. History of delayed feeding or meconium passage was not present in any of the neonates. On examination, cephalhematoma was present in 17 (10.5\%) neonates.

Among the 28 neonates requiring DVET, ABO incompatibility was present in $14(50.0 \%)$ neonates and $\mathrm{Rh}$ incompatibility in $13(46.4 \%)$ neonates.

Table 1. Demographics and Clinical parameters of neonates with hyperbilirubinemia $(\mathrm{n}=162)$

\begin{tabular}{|c|c|c|}
\hline Variables & $\begin{array}{l}\text { Mean } \pm \text { Std } \\
\text { Deviation }\end{array}$ & Range \\
\hline $\begin{array}{l}\text { Gestational age } \\
\text { (weeks) }\end{array}$ & $38.06 \pm 2.13$ & $(35-42) w k s$ \\
\hline $\begin{array}{l}\text { Birth weight } \\
\text { (gm) }\end{array}$ & $2611.72 \pm 389.39$ & $(1800-3500) \mathrm{gm}$ \\
\hline $\begin{array}{l}\text { Weight at } \\
\text { presentation (gm) }\end{array}$ & $2570.74 \pm 413.75$ & $(1350-3500) \mathrm{gm}$ \\
\hline $\begin{array}{l}\text { Age at icterus } \\
\text { noted (hr) }\end{array}$ & $96.87 \pm 71.14$ & $(6-190) \mathrm{hr}$ \\
\hline $\begin{array}{l}\text { Age of } \\
\text { presentation }(\mathrm{hr})\end{array}$ & $102.76 \pm 73.43$ & $(6-190) \mathrm{hr}$ \\
\hline $\begin{array}{l}\text { Total serum } \\
\text { bilirubin }(\mathrm{mg} / \mathrm{dl})\end{array}$ & $21.76 \pm 4.52$ & $(14-30) \mathrm{mg} / \mathrm{dl}$ \\
\hline $\begin{array}{l}\text { Occipitofrontal } \\
\text { circumference } \\
(\mathrm{cm})\end{array}$ & $34.01 \pm 0.84$ & $(32-35) \mathrm{cm}$ \\
\hline
\end{tabular}

$\mathrm{ABO}$ along with $\mathrm{Rh}$ incompatibility was present in eight $(28.6 \%)$ neonates. DCT was positive in six neonates with $\mathrm{ABO}$ incompatibility and nine neonates in $\mathrm{Rh}$ incompatibility. G6PD deficiency was present in four $(14.3 \%)$ neonates. There were three mothers in whom hypothyroidism was present, and these mothers were receiving treatment for the same. Two neonates had abnormal thyroid profile on investigations [Table 2].

Among 28 neonates that required DVET, distribution of various blood groups were $\mathrm{A} \mathrm{Rh}-\mathrm{ve}$ (7.1\%), A Rh +ve (39.2\%), AB Rh +ve (17.8\%), B $\mathrm{Rh}+\mathrm{ve}(28.5 \%)$, and $\mathrm{O} \mathrm{Rh}+\mathrm{ve}(7.1 \%)$. There were no $\mathrm{B} \mathrm{Rh}-\mathrm{ve}, \mathrm{AB} \mathrm{Rh}-\mathrm{ve}$, and $\mathrm{O} \mathrm{Rh}-\mathrm{ve}$ neonates.

Table 2. Risk Factors for Exchange Range Hyperbilirubinemia

\begin{tabular}{|c|c|c|c|c|}
\hline \multirow[t]{2}{*}{ Risk Factors } & \multicolumn{2}{|c|}{ Treatment group } & \multirow{2}{*}{$\begin{array}{l}\text { Total } \\
(N= \\
162)\end{array}$} & \multirow{2}{*}{$\begin{array}{c}\text { P- } \\
\text { value }\end{array}$} \\
\hline & $\begin{array}{c}\text { Double } \\
\text { volume } \\
\text { exchange } \\
\text { transfusion } \\
(\mathrm{N}=\mathbf{2 8})\end{array}$ & $\begin{array}{l}\text { Photo- } \\
\text { therapy } \\
(\mathbf{N}= \\
134)\end{array}$ & & \\
\hline $\begin{array}{l}\text { Small for } \\
\text { gestational age } \\
\text { [preterm }+ \\
\text { IUGR] }\end{array}$ & $\begin{array}{r}20 \\
(71.4 \%)\end{array}$ & $\begin{array}{r}54 \\
(40.3 \%)\end{array}$ & $\begin{array}{r}74 \\
(45.7 \%)\end{array}$ & 0.003 \\
\hline $\begin{array}{l}\text { ABO } \\
\text { incompatibility }\end{array}$ & $\begin{array}{r}14 \\
(50.0 \%)\end{array}$ & $\begin{array}{r}40 \\
(29.9 \%)\end{array}$ & $\begin{array}{r}54 \\
(33.3 \%)\end{array}$ & 0.048 \\
\hline $\begin{array}{l}\mathrm{Rh} \\
\text { incompatibility }\end{array}$ & $\begin{array}{r}13 \\
(46.4 \%)\end{array}$ & $\begin{array}{r}31 \\
(23.1 \%)\end{array}$ & $\begin{array}{r}44 \\
(27.2 \%)\end{array}$ & 0.018 \\
\hline $\begin{array}{l}\text { ABO with Rh } \\
\text { incimpatibility }\end{array}$ & $\begin{array}{r}8 \\
(28.6 \%)\end{array}$ & $\begin{array}{r}20 \\
(14.9 \%)\end{array}$ & $\begin{array}{r}28 \\
(17.3 \%)\end{array}$ & 0.100 \\
\hline $\begin{array}{l}\text { Neonatal } \\
\text { sepsis }\end{array}$ & $\begin{array}{r}6 \\
(21.4 \%)\end{array}$ & $\begin{array}{r}40 \\
(29.9 \%)\end{array}$ & $\begin{array}{r}46 \\
(28.4 \%)\end{array}$ & 0.491 \\
\hline $\begin{array}{l}\text { Sibling treated } \\
\text { for jaundice }\end{array}$ & $\begin{array}{r}15 \\
(53.6 \%)\end{array}$ & $\begin{array}{r}30 \\
(22.4 \%)\end{array}$ & $\begin{array}{r}45 \\
(27.8 \%)\end{array}$ & 0.002 \\
\hline $\begin{array}{l}\text { Cephalhemato } \\
\text { ma }\end{array}$ & $\begin{array}{r}4 \\
(14.3 \%)\end{array}$ & $\begin{array}{r}13 \\
(9.7 \%)\end{array}$ & $\begin{array}{r}17 \\
(10.5 \%)\end{array}$ & 0.499 \\
\hline $\begin{array}{l}\text { Hypothyroidis } \\
\mathrm{m}\end{array}$ & $\begin{array}{r}5 \\
(17.9 \%)\end{array}$ & $\begin{array}{r}20 \\
(14.9 \%)\end{array}$ & $\begin{array}{r}25 \\
(15.4 \%)\end{array}$ & 0.774 \\
\hline $\begin{array}{l}\text { Glucose-6- } \\
\text { phosphate } \\
\text { dehydogenase } \\
\text { (G6PD) } \\
\text { deficiency }\end{array}$ & $\begin{array}{r}4 \\
(14.3 \%)\end{array}$ & $\begin{array}{r}16 \\
(11.9 \%)\end{array}$ & $\begin{array}{r}20 \\
(12.3 \%)\end{array}$ & 0.753 \\
\hline $\begin{array}{l}\text { Oxytocin } \\
\text { during labor }\end{array}$ & $\begin{array}{r}11 \\
(39.3 \%)\end{array}$ & $\begin{array}{r}20 \\
(14.9 \%)\end{array}$ & $\begin{array}{r}31 \\
(19.1 \%)\end{array}$ & 0.007 \\
\hline Birth asphyxia & $\begin{array}{r}5 \\
(17.9 \%)\end{array}$ & $\begin{array}{r}20 \\
(14.9 \%)\end{array}$ & $\begin{array}{r}25 \\
(15.4 \%)\end{array}$ & 0.774 \\
\hline
\end{tabular}


More than one DVET was required in three $(10.7 \%)$ neonates. All of them required DVET twice. Of the three neonates who required more than one exchange transfusion, $\mathrm{Rh}$ incompatibility was present in one neonate; $\mathrm{ABO}$ and $\mathrm{Rh}$ incompatibility was present in two neonates. One neonate expired due to sepsis leading to DIC.

\section{DISCUSSION}

Jaundice is the most common issue in the neonatal period. It is seen in $60 \%$ of term and $80 \%$ of preterm newborns and five to $10 \%$ of these newborns with elevated bilirubin levels required admission to hospital and treatment. ${ }^{6}$ If left untreated, it can lead to severe neurodevelopmental sequelae. In our study we aimed to determine the risk factors of jaundice in our newborns that required DVET for hyperbilirubinemia. The study focused on studying the risk factors for exchange range hyperbilirubinemia. There are limited studies in Nepal that have outlined the risk factors. The risk factors were studied for a high rate of exchange transfusion for hyperbilirubinemia in Eastern part of Nepal.

The mean period of gestation of neonates in our study was $38.06 \pm 2.13$ weeks which was identical to available studies. ${ }^{7-9}$ While mean age of presentation in our study was $102.76 \pm 73.43 \mathrm{hr}$, available literature has reported the age of presentation in days as $4 \pm 1$ days, $4.9 \pm 2.2$ days, and $111.6 \pm 66$ days. ${ }^{2,7,8}$ This wide range in age of presentation can be explained due to differences in the basic etiology underlying hyperbilirubinemia such as $\mathrm{ABO}$ and $\mathrm{Rh}$ incompatibility, G6PD deficiency, and cephalhematoma. Mean age at which icterus was first noticed either by relative or health-care provider was $96.87 \pm 71.14 \mathrm{hr}$. However, the mean age of presentation was 102.76 $\pm 73.43 \mathrm{hr}$ showing a lag period between first notice of icterus and presentation. This could be due to multifactorial causation like delay in seeking care, delayed referral, phototherapy failure, and socio-cultural beliefs of parents. The mean body weight in our study was $2611.72 \pm 389.39 \mathrm{gm}$. Previous studies show mean body weight to be 2.81 $\pm 0.67 \mathrm{~kg}$ with minimum of $1.2 \mathrm{~kg}$ and maximum of $4.3 \mathrm{~kg}^{8}, 2.53 \pm 0.52 \mathrm{~kg}^{7}$, and $3.36 \pm 0.48 \mathrm{~kg} .^{2}$

In our study, 20 (71.4\%) babies were small for gestational age (SGA) that included preterm and intrauterine growth restriction (IUGR). The study demonstrates a preponderance of small for date neonates to develop severe hyperbilirubinemia requiring exchange transfusion with statistically significant results.

$\mathrm{ABO}$ incompatibility was the most common reason for exchange range hyperbilirubinemia in all available studies. It was defined as DCT positivity and or evidence of haemolysis in the peripheral blood smear. In our study, it was present in $50.0 \%$ of the neonates. ${ }^{10,11}$ Variable incidence of $35.9 \%$, $5 \%, 25 \%, 38 \%, 32 \%, 22 \%$ and $15 \%$ has been reported in available literature. ${ }^{12-14}$ The higher rate of DVET in ABO incompatibility in our study could be because of lag period between the onset of jaundice and the time of presentation.

$\mathrm{Rh}$ incompatibility defined as DCT positivity and or evidence of haemolysis in peripheral smear was present in $46.4 \%$ of patients in our study. Studies by Bhat et al., ${ }^{7}$ Davutoğlu et al., ${ }^{8}$ Badiee et al., ${ }^{13}$ Dikshit et al., ${ }^{10}$ Narang et al., ${ }^{11}$ and Chitlangia et al., ${ }^{9}$ had reported $\mathrm{Rh}$ incompatibility in $20.6 \%$, $12.6 \%, 11.7 \%, 10.7 \%, 9.2 \%$ and $6.7 \%$, respectively. This study reflected higher rate of $\mathrm{Rh}$ incompatibility in neonates reflecting geographical and racial variations. G6PD deficiency was detected in $14.3 \%$ of the neonates that required DVET while previous studies show rates of $19.1 \%$, $17.2 \%, 11.4 \%, 6.2 \%$ and $0 \%$ by Badiee et al., ${ }^{13}$ Narang et al., ${ }^{11}$ Davutoğlu et al., ${ }^{8}$ Dikshit et al., ${ }^{10}$ and Chitlangia et al., ${ }^{9}$ respectively. The percentages of neonates with G6PD deficiency remain low in our study. This can be explained by low detection rate during the acute haemolytic episode as young red blood cells have higher G6PD activity. More accurate assessment can be done if these neonates are followed up for G6PD deficiency testing subsequently.

Neonatal sepsis was present in $21.4 \%$ of the babies that required DVET in our study. Only two other studies by Narang et al., ${ }^{11}$ and Dikshit et al., ${ }^{10}$ have reported the incidence of sepsis in neonates requiring exchange transfusion. It was reported to be $24 \%$ and $8 \%$, respectively. However, the higher rate reported by Dikshit et al. may be due to more number of sick infants referred to their hospital.

In our study, oxytocin during labor and sibling treated for jaundice were significantly associated 
with exchange range hyperbilirubinemia. A study by John M. Beazley has reported the association between dose of oxytocin and neonatal hyperbilirubinemia. ${ }^{15}$ A similar study from South Iran has reported the association between previous sibling with significant hyperbilirubinemia and neonatal hyperbilirubinemia. ${ }^{16}$

Extravasation in the form of cephalhematoma in the current study was present in $7.40 \%$ of neonates. Narang et al. reported that $1.4 \%$ of neonates had extravasation. ${ }^{11}$ There are few studies that have described the association between the exchange range hyperbilirubinemia and extravasation among their patients. ${ }^{11}$ History of sibling treated for jaundice was present in $14.81 \%$ of cases in our study which has not been described in any previous study. This is a pointer towards the role of genetic factors in the causation of severe hyperbilirubinemia requiring exchange transfusion. Documented hypothyroidism was present in $11 \%$ of the neonates in our study. Only Sgro et al. ${ }^{2}$ have reported hypothyroidism in neonates with severe hyperbilirubinemia accounting for $1 \%$ of neonates in whom the causes could be found. This difference can be explained by hospital deliveries and screening of neonates admitted to NICU.

Our study does have some limitations. This is a single hospital based observational study and sample size is small. We have not followed up the babies that required DVET for long-term neurological development. However, despite these limitations, we are hopeful that our study would pave pathway for more studies in this field in the future.

\section{CONCLUSIONS}

The neonates who have hyperbilirubinemia may require DVET to protect them from acute bilirubin encephalopathy and kernicterus. The most important risk factors identified in the neonates who required DVET were small for gestational age, $\mathrm{ABO}$ and $\mathrm{Rh}$ incompatibility followed by oxytocin use and sibling treated for jaundice.

\section{REFERENCES}

1. Bhutani VK, Stark AR, Lazzeroni LC, Poland R, Gourley GR, Kazmierczak S, et al. Initial Clinical Testing Evaluation and Risk Assessment for Universal Screening for Hyperbilirubinemia Screening Group. Predischarge screening for severe neonatal hyperbilirubinemia identifies infants who need phototherapy. J Pediatr. 2013;162(3): 477-82. DOI: 10.1016/j.jpeds.2012.08.022

2. Sgro M, Campbell D, Shah V. Incidence and causes of severe neonatal hyperbilirubinemia in Canada. CMAJ. 2006; 175(6):587-90. DOI: 10.1503/cmaj.060328

3. Gamaleldin R, Iskander I, Seoud I, Aboraya H, Aravkin A, Sampson PD, et al. Risk factors for neurotoxicity in newborns with severe neonatal hyperbilirubinemia. Pediatrics. 2011;128(4):925-31. DOI: 10.1542/peds.2011-0206

4. Maisels MJ, Bhutani VK, Bogen D, Newman TB, Stark AR, Watchko JF. Hyperbilirubinemia in the newborn infant $>$ or $=35$ weeks' gestation: an update with clarifications. Paediatrics. 2009;124(4):1193-8. DOI: 10.1542/peds. 2009-0329

5. American Academy of Pediatrics, Subcommittee on Hyperbilirubinemia. Management of hyperbilirubinemia in the newborn infant 35 or more weeks of gestation. Pediatrics. 2004;114(1):297-316. DOI: 10.1542/peds.114.1.297

6. Stanley Ip, Chung M, Kulig J, O'Brien R, Sege R, Glicken S, et al. An evidence-based review of important issues concerning neonatal hyperbilirubinemia. Pediatrics. 2004;114(1):130-53. DOI: 10.1542/peds.114.1.e130

7. Bhat WA, Churoo BA, Iqbal Q, Sheikh MA, Iqbal J, Aziz R. Complication of exchange transfusion at a tertiary care hospital. Curr Pediatr Res. 2011;15(2):97-9.

8. Davutoğlu M, Garipardiç M, Güler E, Karabiber H, Erhan D. The etiology of severe neonatal hyperbilirubinemia and complications of exchange transfusion. Turk J Pediatr. 2010;52(2):163-6. PMID: 20560252

9. Chitlangia M, Shah GS, Poudel P, Mishra OP. Adverse events of exchange transfusion in neonatal hyperbilirubinemia. J Nepal Paediatr Soc. 2014; 34(1):7-13. DOI: https://doi.org/10.3126/jnps.v34i1.9030

10. Dikshit SK, Gupta PK. Exchange transfusion in neonatal hyperbilirubinemia. Indian Pediatr. 1989;26(11):1139-45. PMID: 2630476 
11. Narang A, Gathwala G, Kumar P. Neonatal jaundice: An analysis of 551 cases. Indian Pediatr. 1997;34(5):429-32. PMID: 9332119

12. Mac Donald MG, Mullet MD, Seshia MM, editors. Avery's Neonatology Pathophysiology and Management of the Newborn. 6th ed. Philadelphia: Lippincott Williams \& Wilkins; 2005. p. 775

13. Badiee Z. Exchange transfusion in neonatal hyperbilirubinaemia: Experience in Isfahan, Iran. Singapore Med J . 2007;48(5):421-3. PMID: 17453099

14. Shah A, Shah CK, Shah V. Study of hematological parameters among neonates admitted with neonatal jaundice. J Evol Med Dent Sci .2012;1(3):203-8. DOI: https://doi.org/10.14260/jemds/32

15. Beazley JM, Alderman B. Neonatal hyperbilirubinemia following the use of oxytocin in labour. BJOG. 1975;82(4): 265-71. DOI: https://doi.org/10.1111/j.1471-0528.1975.tb00632.x

16. Najib KS, Sak Fi F, Hemmati F, Inaloo S. Incidence, Risk Factors and Causes of Severe Neonatal Hyperbilirubinemia in the South of Iran (Fars Province). Iran Red Crescent Med J. 2013;15(3):260-3. DOI: $10.5812 /$ ircmj.3337 